\title{
Pupils' Questions in Dialogic Teaching from the Perspective of Pedagogical Research
}

\author{
Hana Lukášová - Marie Pavelková* \\ Received: May 23, 2017; received in revised form: September 18, 2017; \\ accepted: September 19, 2017
}

\begin{abstract}
:
Introduction: In our conditions and in the world, there is a tradition of the sequence of sequential communication exchanges in the interaction of a teacher and pupils, which was examined in the analysis of the processes and structures in educational communication. This tradition can be continued from the perspective of research at the 1 st stage of elementary school education.

Purpose: The aim of the study is to present the findings of a research on the issues of pupils' questions. The research question is whether the existing results of educational research on the educational interaction and teacher-student communication in the educational process at the first stage of elementary schools also capture the characteristics of pupils' questions. We will investigate the perception of dialogic teaching and pupils' question in educational research. The sequence of sequential communication exchanges in the interaction between teachers and pupils, which was examined in the analysis of the processes and structures of educational communication, has in our country and in the world a tradition which can be followed in terms of research on teaching at the first stage of primary schools. One of the aspects of research on the interaction and communication in the classroom are the views of teachers who are discovering what a learner knows, and what he/she thinks about the communicated content and curriculum. But we are mainly interested in the results of educational research from the perspective of the pupil and his/her questions in the classroom.

Methods: In our research, our intention was to analyse pupils' questions which are to supplement their knowledge, or to find out more information that would help them deal with learning tasks. We were interested in previous investigations and were seeking for clarification whether the pupils' questions are inconsistent, which would reveal misconceptions and wrong ideas in the understanding of the teaching content.

Conclusions: The most frequently, pupils' answer to the teacher's questions were detected. The conclusions show the current results of pedagogical research in the context of dialogic teaching, they do not capture the characteristics of pupils' questions in teaching at the 1 st grade of elementary schools.
\end{abstract}

Key words: dialogue in education, educational research, pupils' questions, pupils' participation.

\footnotetext{
Hana Lukášová, Tomas Bata University in Zlín, Faculty of Humanities, Zlín, Czech Republic; hlukasova@fhs.utb.cz

Marie Pavelková, Tomas Bata University in Zlín, Faculty of Humanities, Zlín, Czech Republic; mpavelkova@fhs.utb.cz
} 


\section{Acta Educationis Generalis \\ volume 7, 2017, issue 3}

\section{Introduction}

In the introduction of our paper, we will describe the views on pupils' questions in selected pedagogical research. The studies that were selected correspond with the position of a pupil's questions in the teaching dialogue. Pupils' questions can never stand alone in pedagogical research because it is logical that a pupil's question is a part of a communicative interaction with the pupil's participation in the pedagogical communication (Šed'ová, Sedláček, Švaříček, \& Šalamounová, 2014; Šed'ová \& Sedláček, 2015; Šed'ová, 2015; Šed'ová, Sucháček \& Majcík, 2015; Navrátilová, 2017). In general, we can state that pupil's questions are being omitted in current scientific discourse based on F. Tůma's overview study (2014), which we would like to extend by our overview study, critically analyses of 21 studies published in the span of 1990 2012. The author selected the main thoughts of the studies in his overview: communication in the form of a dialogue in education - a majority of scientific studies from the selection focused on teachers' questions, their evaluation and the following questions from pupils. The author presents dialogism from the view of the differences in the approaches to the character of interaction between the speaker and the role of the context. The author presents his finding that six of 13 selected empirical studies analysed focused on one stage of the IRF structure only. Simply put, communication exchanges initiated by teachers predominate in education, which is why the author reflected on whether it is advisable to consider such studies as examples corresponding to the dialogic structure. For our purposes, it means that when there is a one-way IRF structure $^{1}$, there is no space for a pupil to ask questions. In the overall evaluation, the author states that in the period examined (1990-2012), it is possible to derive from the analysis of those studies that monologism ${ }^{2}$ prevails. This is where Tůma entwines his overview with Mareš's overview (1990) and states that the author's criticism points to the absence of searching for a wider context and relations in communication, and that here is a segmentation of activities into disjunctive categories - at least prior to 1989, but continuing to some extent in years 19902012.

Jiří Mareš (2016), in his extensive overview, reflects on the pedagogical research on interaction and teacher - pupil communication in education in the period from 1968 to 2015. Similarly, he discusses such communication structures as IRF/IRE ${ }^{3}$ and tries to view the development of the mentioned structures as it changes in time. Nathan, Eilam and Kim (as cited in Mareš, 2016) showed that the communicative structure changes remarkably during education focused on collective problem solving with the

\footnotetext{
${ }^{1}$ It is a communication based on the IRF structure - teacher initiation - student replica - pupil feedback from teacher (initiation-reaction-follow-up), see Mareš (2016).

${ }^{2}$ An individual is the key unit for a monologue. The individual is viewed through a coupling metaphor, which implies understanding the interaction as a one-way process. Simply put, a passive role of the listener is assumed here (Tůma, 2016).

3 The IRF structure is perceived as an initiation performed by the teacher - pupil replica - teacher feedback for the pupil. Communicative exchanges that the teacher initiates prevail (Mareš, 2016). IRE stands for initiation response - evaluation. Further, Mehan (1979, as cited in Mareš, 2016) developed I - initiation, he distinguished between: directive initiation; informative initiation; the choice of the pupil the teacher calls upon; product elicitation; process elicitation; metaprocess elicitation. R, i.e. pupil's replies - reaction, acceptance of something, choice of possible answers; process of responding, metaprocess of responding and non-reacting to teacher initiation. The author points out that the key role in this structure is primarily played by E, i.e. the way of evaluation.
} 


\section{Acta Educationis Generalis \\ volume 7, 2017, issue 3}

participation of both the pupils and the teacher. Here, the middle part of the IRE structure transforms into D (demonstration); the teacher establishing the problem motivates some pupils to express themselves more extensively, initiates a process in which they demonstrate their way of thinking. According to the above group of authors, the new structure IDE arises (initiation - demonstration - evaluation). The pupils have enough space to express their views (demonstration) and to discuss them with the teacher (evaluation). From our researcher's view, there can be a space for a pupil's need to ask questions. It is especially about breaking the traditional IRF structure, and as Šed'ová and Sedláček (2015) state in their research, in dialogic education it is necessary to give pupils space for frequent and long responses. For our purposes, the following authors' finding is very important, "Our analysis proves that if there are shifts in the communicative behaviour of pupils, it is caused by shifts in the teacher's behaviour" (Šedová \& Sedláček, 2015, p. 53).

\section{Teacher and Pupils in Dialogue}

In her research, Šed'ová (2015) also focused on the position of a pupil's question in the education process from the point of view of power in an educational dialogue. She argues that power in a classroom is not automatically attributed to a teacher because a pupil can influence other pupils' behaviour as well. Preference of power in educational communication leads to shifting the dominance between the teacher and pupils in the way that both groups pursue their goals. Samuhelová (as cited in Mareš 2016) states that on the basis of the relationship of dominance and subordination, the direction of communication can also be vertical (downwards, upwards). The author presents her empirical research, a study in which she identifies 18 communication structures on the basis of an analysis of 22 classes at the second stage of elementary schools (meaning from the 6th to the 9th grade of elementary school in the Czech educational system). The most frequently occurring structures were: a) a two-way vertical communication structure during which there is a dialogue between the teacher and a pupil, including feedback, b) a one-way vertical structure between the teacher and a group or the whole class without feedback and c) a one-way vertical structure in which the teacher addresses a particular pupil but there is no feedback from him/her. For our purposes, the two-way vertical communication structure is important as there is a space for pupils' questions. Švaříček, Šed'ová and Šalamounová (2012) extend that two-way communication structure by mentioning the pupils' productive involvement in the communication in education, which basically means that pupils speak aloud, teachers listen to them and answer their questions; similarly, pupils ask questions themselves and comment on others' reactions, speak about things or comment on the results of their work. The team of authors Šed'ová, Švaříček and Šalamounová (2012) from the Department of Educational Sciences at the Faculty of Arts at Masaryk University published a book in which they elaborated and presented their original research which included long-term observations and video recordings of classes at the second stage of elementary schools. It is concerned with the nature of both teachers' and pupils' questions. Here, we present a typology which is crucial for our overview. The authors specify pupils' questions by trying to answer the following questions about the context in which the questions were asked: 


\section{Acta Educationis Generalis \\ volume 7, 2017, issue 3}

1. Finding out necessary information, or "need to know" questions. A pupil called Mark asks: What is the pronunciation of this name?

2. Questions out of curiosity, or "I'd like to know" questions. Mark asks: Did you buy it for your own money?

3. "I don't understand" questions or questions requiring explanation, i.e. in the words of the authors, autonomous questions, when the question seeks details of a problem. Adeleide asks: Was it indecent or what?

4. Polemic about a problem is expressed by questions like "Isn't it different", or by confrontation with the understanding. Tony asks: Miss, is "What have I not seen in my life" the first sentence? (Švaříček, Šed'ová, \& Šalamounová, 2012, p. 148).

Those types of pupil's questions are perceived by the authors as the most frequently asked questions in the teacher-pupil educational dialogue at the second stage of elementary schools. Asking questions is also connected to a pupil's willingness and desire to ask questions. In this field, Šed'ová and Šalamounová (2016) present the socalled Pygmalion effect, in which teachers in some way notice the pupils' characteristics and draw conclusions regarding their abilities, further, on the basis of such a subjective conclusion, they then lead pupils by asking them more difficult or, on the contrary, more trivial questions. For the pupils, it is basically a definition of themselves; they accept such definitions as their own and they adjust their behaviour accordingly. Other researches react to this situation (Šed'ová \& Sedláček, 2015; Šed’ová \& Šalamounová, 2016) and specify that patterns of pupils' participation are influenced by the teacher's evaluation and a subsequent teacher's reaction to a remarkable extent. In fact, such an evaluation is basically a label. The authors suggest that if we want to avoid labelling ${ }^{4}$ and making a particular pupil's label a reality, it is easier to engage all pupils in the class in communication, even those whom we perceive as weak. According to the authors, the results prove that pupils engage in communication primarily via their teacher's question (2 pupils in the case of Šed'ová and Šalamounová's research (2015)) which is a typical way of pupil participation. From this finding, we can derive a conclusion that there is a lack of space for communication offering pupils' an opportunity to ask questions. The results also show that a pupil's participation is a product of social interactions ${ }^{5}$ and we can see that even weak pupils can participate adequately and become involved in a difficult and cognitively demanding discussion. We can see a match in the research by Šed'ová and Šalamounová (2016) and Šed'ová and Sedláček (2015), who argue that when teachers ask any type of questions, the mechanism of their treatment of pupils' responses stays similar. In addition, the analysis by Sedláček and Šalamounová (2015) demonstrated that the presumption, "If pupils are supposed to talk a lot, the teacher has to ask a lot" is not valid. The real situation is described by Šed'ová, Šalamounová and Švaříček (2014), which present the results of their research, where it is clear that the Czech teachers are trying to teach in accordance with the principles of dialogical teaching, they use dialogic activities, but the real dialogical form at the second grade of

\footnotetext{
${ }^{4}$ Labelling is described as an indication of the pupil's behaviour, and the pupil fixes that designation for that type.

${ }^{5}$ While it is certain that the importance of pupils' attributes such as shyness or assertiveness cannot be underestimated.
} 


\section{Acta Educationis Generalis \\ volume 7, 2017, issue 3}

elementary schools appears only sporadically (Šed’ová, Šalamounová, \& Švaříček, 2014, p. 283).

\section{The actual presence of dialogic and participative education in pedagogical interaction and communication}

Dialogic education is a type of education which is about a mutual exchange of communication sequences between a teacher and a pupil. The position of dialogic education is clearly explained by Mortimer and Scott (2003, as cited in Lehesvuori \& Viiri, 2015) as a dimension of educational communication: interactive vs. noninteractive, authoritative vs. dialogic. Empirically-based pedagogical research (Lehesvuori \& Viiri, 2015; Šed'ová, 2017) state that the goal of dialogic education is to make it possible for pupils to express their thoughts beyond gathering and memorizing facts: it is not primarily about pupils speaking more often or for longer, but is rather about them taking the initiative and being autonomous in education. Authors view dialogic education as participation of those involved in the process of education because, as Šed'ová and Šalamounová (2016) state, participation is based on the sociocultural theory presented primarily by Vygotsky (1976, as cited in Šed'ová \& Šalamounová, 2016) while each psychological function appears twice in a child's development:

1) on the social level - interaction with other people; and

2) later, on the individual level - internalization of psychological processes. The authors lean towards the term commognition ${ }^{6}$ as an emphasis on the inseparability of these two terms. In his overview, Mareš (2014) focused on the interaction in communication as well. He characterizes it as a dialogically interactive approach (D/I): a teacher brings about a discussion which makes him or her an initiator, pupils present their own opinions and life experiences, the teacher does not evaluate their opinions and he or she only moderates them ${ }^{7}$ (Mareš, 2016, p. 275). Šed'ová and Šalamounová (2016) state in their research that there is a complementary assumption that various degrees of participation are evoked by the interacting behaviour of the teacher, and, further, that they present a proportionality of pupils' engagement in education. They state that successful pupils engage more in education, or rather speak more often, but they emphasize that it is caused by the fact that these children raise their hand more often. We can present their finding as an often-criticized direct proportion, such as, "If a pupil raises his or her hand more often, the teacher calls on him or her more often". If we focus on the balance in the participation of both groups, there is also a direct relationship, "In case of a pupil's incorrect answer, the teacher is more likely to criticize the unsuccessful pupil". The authors interpret the results as follows: teachers, apparently unintentionally, encourage actively the participation of mainly those pupils on which they place high expectations.

We can approach operationalization from the aspect of pupils as a component of dialogic education, with a focus their engagement in a form of participation in the educational communication (Šed'ová \& Sedláček, 2015). The authors say that the level of a pupil's

\footnotetext{
6 The term commognition originated as a composite of communication and cognition.

${ }^{7}$ Mareš (2016) mentions Scott (2006) as the author of this approach, who described it as IR-P-R-P, where P means insinuating, signalling (prompting).
} 


\section{Acta Educationis Generalis \\ volume 7, 2017, issue 3}

focused participation ${ }^{8}$ in education can be increased by a directed employment of the components of dialogic education. This approach was also investigated by Mueller, Yankelewitz and Maher (2014), who point out the need for developing the awareness of situations in the classroom which support discussions about the teacher's role in the classroom. In their study, the authors analyse and discuss specific teacher approaches which lead to the creation of conditions for pupils and teachers in which they constructed mathematical methods together. The research showed that creating favourable conditions supports thoughtful education in Mathematics. The activity includes a combination of the following:

a) active pupils;

b) observant and involved teachers who pay attention to the development of their attitudes towards pupils and their development;

c) suitable and creative tasks which encourage pupils to widen their knowledge about how they can build their results;

d) pupils' cooperation which enables an exchange of ideas, and

e) creating a respectful climate and welcoming pupils' ideas, discussion and finding alternative ways of work.

Under such conditions, even young children can develop trust in their ability to solve problems and create arguments for solving tasks (Yackel \& Hanna, 2003 as cited in Mueller, Yankelewitz, \& Maher, 2014). Another point of view is presented by RojasDrummod et al. (2016, p. 46), which find it preferable not to use bound or confined queries for a productive dialogue, but to provide extensive possibilities for reasoning. The study by Norenes and Ludvigsen (2016) features a research that focused on Wiki computer programs and encouraging verbal interaction between pupils and teachers. The authors discuss that day-to-day technology can serve as a means of transforming discourse and student involvement into dialogue, and the teacher deliberately creates this dialogue (Norenes \& Ludvigsen, 2016, p. 68).

\section{Research questions and methodology}

Our intention is to critically evaluate the results of pedagogical research in the studies which were focused on dialogic education research and pupil participation in the education at the second stage of elementary schools, and also to find out how the studies could inspire the pedagogical research of pupils' questions in dialogic and participative education in elementary education.

Research questions:

1. Do the current results of pedagogical research in the context of dialogic and participative education capture the characteristics of pupils' questions as well?

2. In what way is dialogic and participative education understood in pedagogical research and can we use the mentioned characteristics for an analysis of education at the first stage of elementary school?

3. Which classes have been involved in the research on dialogic and participative education up to now?

\footnotetext{
${ }^{8}$ In the above-mentioned research, the participation was operationalized as 1) class time which pupils use for discourse; 2) the opportunity of pupils to elaborate discourses; 3) the triadic interaction, namely the communication among more agents than one pupil and a teacher.
} 


\section{Acta Educationis Generalis \\ volume 7, 2017, issue 3}

We selected Mareš's (2013, p. 432) taxonomy, which can help us to create an overview of scientific studies, gather, sort and evaluate the results of up-to-date efforts in research on dialogic education. We intend to answer our research questions in this study. On the basis of the studies listed in the overview, we will then propose how the findings about the appearance of pupils' question might be used in our research methods and for the selection of a research sample in the future.

We will choose scientific studies concerned with dialogic and participative education in the context of pedagogic interaction and teacher-pupil communication. Tůma's (2014) overview analysing research in this field from 1990 to 2012 will be crucial for us. We would like to extend this study in a way that we will respect previous findings regarding pupils' questions in education from 2013 to 2016. In our overview study, we will include the analysis of findings from the studies reviewed in scientific magazines, especially Pedagogická orientace, Pedagogika and Orbis Scholae and also the scientific magazine Studia paedagogica. The crucial criterion in the selection was the thematic connection of dialogic education and pedagogic research, which we realized by manual selection and selection of studies, whose title contained the following key words: dialogue, questions, interactions, communication and participation in education. A high quality of the scientific studies reviewed in these magazines and the fact that they are indexed in international databases (Scopus, ERIH) ${ }^{9}$ was also an important factor for us. The actual selection of scientific magazines emerged from the finding that, in 2012, the group of authors Švařŕček, Šed'ová and Šalamounová from the University in Brno published a book Komunikace ve školní trrídě (Communication in classroom) and its reviews were published in significant Czech periodicals, such as Pedagogická orientace (2/2012), Orbis Scholae (3/2012) and Pedagogika (1/2013). Additionally, in 2016, the authors of the book reacted to J. Mareš's review of the study, which is an interesting dialogue that deals with the topic we are researching right now (see Švaříček, Šed'ová, \& Šalamounová, 2016). We are aware of the methodological limits which emerge from the fact that there were a number of research outcomes on one research task. To minimize the risk, we present the research aims from the studies whose outcomes differ.

Because of our decision to extend Tůma's study (2014), we presented the results of analysis in similar ways as in the already-mentioned overview studies (for further details, see Table 1).

Table 1

An overview of research to the topic of a pupil's question in dialogic and participative education

\begin{tabular}{|c|c|c|c|c|}
\hline Author & $\begin{array}{c}\text { Research } \\
\text { aims/questions }\end{array}$ & $\begin{array}{c}\text { The level } \\
\text { of education }\end{array}$ & Subjects & Locality \\
\hline $\begin{array}{l}\text { Dina Yankelewitz } \\
\text { Mercy College } \\
\text { Carolyn Maher } \\
\text { Rutgers } \\
\text { University }\end{array}$ & $\begin{array}{l}\text { Describe specific } \\
\text { teaching steps } \\
\text { which lead to the } \\
\text { formation of } \\
\text { pupils' ideas, }\end{array}$ & High school & Mathematics & $\begin{array}{l}\text { The United } \\
\text { States of } \\
\text { America }\end{array}$ \\
\hline
\end{tabular}

\footnotetext{
${ }^{9}$ See: List of reviewed non-imprinted periodicals published in the Czech Republic Approved by the Research and Development Council on 20 June 2008.
} 


\begin{tabular}{|c|c|c|c|c|}
\hline 2014 & $\begin{array}{l}\text { strategies and } \\
\text { suggestions for } \\
\text { solving } \\
\text { mathematical } \\
\text { tasks. }\end{array}$ & & & \\
\hline $\begin{array}{l}\text { František Tůma } \\
2014\end{array}$ & $\begin{array}{l}\text { Critically discuss } \\
\text { the studies dealing } \\
\text { with an interaction } \\
\text { in the classroom } \\
\text { with respect } \\
\text { towards how } \\
\text { dialogism is } \\
\text { applied in them. }\end{array}$ & Unspecified & Unspecified & Unspecified \\
\hline $\begin{array}{l}\text { Klára Šed'ová, } \\
\text { Zuzana } \\
\text { Šalamounová, } \\
\text { Roman Švaříček, } \\
\text { Martin Sedláček } \\
2014\end{array}$ & $\begin{array}{l}\text { The aim was to } \\
\text { determine how } \\
\text { much the } \\
\text { participation in the } \\
\text { programme led to } \\
\text { an actual change } \\
\text { in teacher student } \\
\text { communication in } \\
\text { the classroom. }\end{array}$ & $\begin{array}{l}\text { The second } \\
\text { stage of } \\
\text { elementary } \\
\text { school }\end{array}$ & $\begin{array}{l}\text { Civics } \\
\text { Czech } \\
\text { language } \\
\text { History }\end{array}$ & $\begin{array}{l}\text { South- } \\
\text { Moravian } \\
\text { region }\end{array}$ \\
\hline $\begin{array}{l}\text { Luisa Molinari, } \\
\text { Consuelo Mameli } \\
\text { (2015) }\end{array}$ & $\begin{array}{l}\text { In what way can } \\
\text { connecting } \\
\text { structural and } \\
\text { emergency } \\
\text { components of } \\
\text { discourse } \\
\text { processes occur, } \\
\text { and how can such } \\
\text { connections } \\
\text { contribute to the } \\
\text { creation of } \\
\text { opportunities for } \\
\text { learning? }\end{array}$ & $\begin{array}{l}\text { Elementary } \\
\text { education }\end{array}$ & Unspecified & Italy \\
\hline $\begin{array}{l}\text { Martin Sedláček } \\
\text { Klára Šed’ová } \\
2015\end{array}$ & $\begin{array}{l}\text { What kind of } \\
\text { influence do the } \\
\text { selected } \\
\text { characteristics of } \\
\text { educational } \\
\text { communication } \\
\text { have on } \\
\text { subjectively } \\
\text { perceived learning } \\
\text { of pupils in } \\
\text { humanities? }\end{array}$ & $\begin{array}{l}\text { The second } \\
\text { stage of } \\
\text { elementary } \\
\text { school }\end{array}$ & $\begin{array}{l}\text { Civics } \\
\text { Czech } \\
\text { language } \\
\text { History }\end{array}$ & $\begin{array}{l}\text { South- } \\
\text { Moravian } \\
\text { region }\end{array}$ \\
\hline Klára Šed’ová & 1) Did the level of & The second & Civics & South- \\
\hline
\end{tabular}




\section{Acta Educationis Generalis \\ volume 7, 2017, issue 3}

\begin{tabular}{|c|c|c|c|c|}
\hline $\begin{array}{l}\text { Martin Sedláček } \\
2015\end{array}$ & $\begin{array}{l}\text { pupil participation } \\
\text { rise after the } \\
\text { intervention? } \\
\text { 2) In what ways } \\
\text { do teachers reach } \\
\text { higher pupil } \\
\text { participation? }\end{array}$ & $\begin{array}{l}\text { stage of } \\
\text { elementary } \\
\text { school }\end{array}$ & $\begin{array}{l}\text { Czech } \\
\text { language }\end{array}$ & $\begin{array}{l}\text { Moravian } \\
\text { region }\end{array}$ \\
\hline $\begin{array}{l}\text { Klára Šed’ová } \\
2015\end{array}$ & $\begin{array}{l}\text { What does the } \\
\text { research focused } \\
\text { on power relations } \\
\text { between the } \\
\text { teacher and pupils } \\
\text { bring in the ontext } \\
\text { of the so-called } \\
\text { dialogic } \\
\text { education? }\end{array}$ & $\begin{array}{l}\text { The second } \\
\text { stage of } \\
\text { elementary } \\
\text { school }\end{array}$ & $\begin{array}{l}\text { Civics } \\
\text { Czech } \\
\text { language }\end{array}$ & $\begin{array}{l}\text { South- } \\
\text { Moravian } \\
\text { region }\end{array}$ \\
\hline $\begin{array}{l}\text { Sami } \\
\text { Lehesvuiri, } \\
\text { Jouni Viiri } \\
2015\end{array}$ & $\begin{array}{l}\text { What are the } \\
\text { methods from } \\
\text { theory to practice } \\
\text { and from the } \\
\text { planning of } \\
\text { dialogic education } \\
\text { to reflection? }\end{array}$ & $\begin{array}{l}\text { lower } \\
\text { secondary } \\
\text { and higher } \\
\text { secondary } \\
\text { level of } \\
\text { education }\end{array}$ & $\begin{array}{l}\text { Natural } \\
\text { sciences }\end{array}$ & $\begin{array}{l}\text { South- } \\
\text { eastern } \\
\text { Finland }\end{array}$ \\
\hline $\begin{array}{l}\text { Jiří Mareš } \\
2016\end{array}$ & $\begin{array}{l}\text { What did the } \\
\text { research on } \\
\text { processes and } \\
\text { structures in } \\
\text { educational } \\
\text { communication } \\
\text { bring in the past } \\
\text { and at present? }\end{array}$ & Unspecified & unspecified & Unspecified \\
\hline $\begin{array}{l}\text { Klára Šred'ová, } \\
\text { Petr Sucháček, } \\
\text { Martin Majcík } \\
2015\end{array}$ & $\begin{array}{l}\text { Is there an uneven } \\
\text { share of pupils in } \\
\text { verbal } \\
\text { participation? } \\
\text { Is there a } \\
\text { relationship } \\
\text { between a pupil's } \\
\text { verbal } \\
\text { communication } \\
\text { and success at } \\
\text { school? How does } \\
\text { the disproportion } \\
\text { in the participation } \\
\text { of pupils of } \\
\text { varying school } \\
\text { success occur? }\end{array}$ & $\begin{array}{l}\text { The second } \\
\text { stage of } \\
\text { elementary } \\
\text { school }\end{array}$ & $\begin{array}{l}\text { Czech } \\
\text { language }\end{array}$ & $\begin{array}{l}\text { South- } \\
\text { Moravian } \\
\text { region }\end{array}$ \\
\hline
\end{tabular}


Acta Educationis Generalis

volume 7, 2017, issue 3

\begin{tabular}{|c|c|c|c|c|}
\hline $\begin{array}{l}\text { Klára Šed'ová, } \\
\text { Zuzana } \\
\text { Šalamounová } \\
2016\end{array}$ & $\begin{array}{l}\text { How did the shift } \\
\text { in the style of } \\
\text { education take } \\
\text { place and what } \\
\text { was it caused by? }\end{array}$ & $\begin{array}{l}\text { The second } \\
\text { stage of } \\
\text { elementary } \\
\text { school }\end{array}$ & Literature & $\begin{array}{l}\text { South- } \\
\text { Moravian } \\
\text { region }\end{array}$ \\
\hline
\end{tabular}

We hope that we will manage to contribute to learning about professional pedagogical community via a microscopic view on pupils' questions in elementary education. On the basis of research results, we will try to stimulate teachers' interest in an active participation of pupils by encouraging pupils' questions in elementary education conditions.

\section{Results of the overview study and discussion}

The answer to the first research question on whether the up-to-date results of pedagogical research in the context of dialogic education capture the characteristics of pupil's questions is "no". As the previous overview table shows (Tüma, 2014), neither of the studies is focused on the characteristics of a pupil's questions at the first stage of elementary schools. Based on the overview focused on the analysis of other studies, we can confirm the lack of interest in pupils' questions in education at the first stage of elementary schools. The only exception is Pstružinová's study (1992), which was focused on the identification of the types and the frequency of a pupil's questions (and answers to them) in selected classes of children at younger school age. The sample reached the 8th year of elementary school. Makovská's study (2011), presenting the answer to the following two research questions, is also interesting: What are the characteristics of pupils' lines in educational communication? and How do pupils proceed in looking for the "right" answer? From the aspect of dialogism, the author of the overview study states that pupils' lines are looked upon separately, they are not perceived in the context, and the focus is on the individual's activity. It is a fact interesting for our research that the authors perceive this interaction as neobehaviouristic ${ }^{10}$, by which we mean stimulus $\rightarrow$ internal factors (organism) $\rightarrow$ a pupil's reaction $\rightarrow$ stabilization (Tůma, 2014). It seems that here we can find space for the possible occurrence of a pupil's question.

The answer to the second research question (which was focused on the way we understand dialogic education in pedagogic research) is that the up-to-date results of research in the context of dialogic and participative education do not capture the characteristics of pupils' questions in education at the first stage of elementary schools. The way in which dialogic and participative education is understood in the current pedagogical research is paradigmatically usable and can be inspiring for a further analysis of education at the first stage of elementary schools with respect to pupil's questions. In research, dialogism is understood as a mutual exchange of communication sequences between a teacher and a pupil. The analysed studies also agree on an important thing - dialogic education creates a suitable environment and conditions for the participation and interaction of participants in pedagogical communication and in the construction of various methods in for a teaching subject. It is safe to say that, under our

\footnotetext{
${ }^{10}$ E. C. Tolman extended Behaviorism to NeoBehaviorism. Traditional stimulus - the reaction has spread over the body. Thus, S-O-R.
} 


\section{Acta Educationis Generalis \\ volume 7, 2017, issue 3}

conditions, dialogism is a convenient terrain, and the studies by Lehesvuori and Viiri (2015) and Šed'ová (2015) are authoritative for us; the authors state that the goal of dialogic education is to make it possible for pupils to express ideas beyond gathering and memorizing facts, while the primary intention is not that they speak more often or longer, but that they are initiative and autonomous in their education. In a pupil's autonomy, there is space for possible pupils' questions.

The last research question was which classes have been the concern of dialogic and participative education research? In general, we can answer that research was concerned with the subjects at the second stage of elementary schools, and more than one half of them included Czech language and literature, Civics or History ${ }^{11}$ classes. One foreign study from our overview focuses on the first stage of elementary schools.

\section{Conclusion}

The findings answering our research questions can be summarized into the following conclusions.

The current results of pedagogical research in the context of dialogic education do not capture the characteristics of pupils' questions in education at the first stage of elementary schools, which is why it will be useful to focus on this direction.

The way in which dialogic and participative education is understood in the current pedagogical research is paradigmatically usable and it can be inspiring for a further analysis of education at the first stage of elementary schools with respect to pupils' questions.

Up to now, the dialogic and participative education research has been concerned with some selected subjects at the second stage of elementary schools only. That is why we cannot directly use them for a comparison with the results we anticipated in our own research realized at the first stage of elementary schools and on Mathematics.

From the results of our analysis, it is obvious that our research intentions for the future could fill a blank space in pedagogical research. In the studies magazines, there is no research presenting the results of dialogically approached education at the first stage of elementary schools. Our purpose is to describe and characterize pupils' questions in dialogic education at this stage of education. Also, we want to identify what the occurrence of the pupil's questions relies on. In the future, we will be interested in the approaches towards stimulation and usage of pupil's questions teachers apply in pedagogical interaction and communication in elementary education. We will also try to answer the question whether teachers involved in elementary education need the knowledge about pupils' questions for their practice and whether current pedagogical training on these needs fulfils and stimulates the abilities to create space for pupils' questions. In the first phase, we will focus on the possibilities of pupils' questions in Mathematics at the first stage of elementary schools, where the basics of pupil participation can be found in the form of seeking new possibilities for the future.

\footnotetext{
11 We know that this predominance was caused by the fact that the authors Šed'ová, Švaříček and Šalamounová from the Institute of Pedagogical Sciences of the Faculty of Arts of Masaryk University presented a research which included a long-term observation and video recordings in the second grade of the elementary schools on these subjects and the majority of these studies drew their data from of this research.
} 


\section{Acta Educationis Generalis \\ volume 7, 2017, issue 3}

\section{References}

Lehesvuori, S., \& Viiri, J. (2015). Od teorie k praxi. Od plánování dialogického vyučování k jeho reflexi. Studie pedagogika, 20(2), 9-31.

Makovská, Z. (2011). Žákovské strategie při hledání odpovědí na otázky učitele. Studia pedagogica, 16(1), 47-70.

Mareš, J. (1990). Zamyšlení nad čs. výzkumy pedagogické interakce a komunikace. In Súčasný stav a perspektívy pedagogického výskumu (pp. 85-104). Bratislava: Ústav experimentálnej pedagogiky SAV.

Mareš, J. (2016). Zkoumání procesů a struktur ve výukové komunikaci: historie a současnost. Pedagogika, 66(3), 250-289.

Molinari, L. \& Mameli, C. (2015). Triadic interactions in classroom discourse. Studia paedagogica, 20(3), 9-28.

Mueller, M. Yankelewitz, D., \& Maher, C. (2014). Teachers Promoting Student Mathematical Reasoning. Investigations in Mathematics Learning, 7(2), 1-20.

Navrátilová, H. (2017). Children's Initiations in Communication with Preschool Teachers. Acta Educationis Generalis, 7(2), 42-55. doi: 10.1515/atd-2017-0012

Norenes, O. S., \& Ludvigsen, S. (2016). Language use and participation in discourse in the mathematics classroom: When students write together at an online website. Learning, Culture and Social Interaction, 11, 66-84.

Pstružinová, J. (1992). Některé pedagogicko psychologické aspekty učitelových otázek. Pedagogika, 42(2), 223-228.

Rojas-Drummod, S., Maine, F., Alarcoón, M., Trigo, L. A., Barrera, J. M., Mazón, N., Vélez, M., \& Hoffmann R. (2017). Dialogic literacy: Talking, reading and writing among primary school children. Learning, Culture and Social Interaction, 12, 4562.

Sedláček, M., \& Šed’ová, K. (2015). Komunikace ve školní třídě a žákovské učení. Orbis Scholae, 9(1), 83-101.

Šed'ová, K. (2015). Moc v dialogickém vyučování. Pedagogická orientace, 25(1), 32-62.

Šed'ová, K., \& Sedláček, M. (2015). Žákovská participace jako předmět akčního výzkumu. Studia Pedagogica, 20(2), 33-58.

Šed'ová, K., Sucháček, P., \& Majcík, M. (2015). Kdo mluví? Participace žáků na výukové komunikaci na druhém stupni základní školy. Pedagogika, 65(2), 143-162.

Šed’ová, K., \& Šalamounová, Z. (2016). Dialogické vyučování jako realizace produktivní kultury vyučování a učení v literární výchově: jak iniciovat a udržovat změnu. Orbis Schole, 10 (2), 47-69.

Šed'ová, K., Šalamounová, Z., \& Švaříček, R. (2014). Troubles with dialogic teaching. Learning, Culture and Social Interaction, 3, 274-285.

Šed'ová, K., Švaříček, R., Sedláček, M., \& Šalamounová, Z. (2014). On the way to dialogic teaching: Action research as a means to chase classroom discourse. Studia Pedagogica, 21(3), 9-43.

Švaříček, R., Šed’ová, K., \& Šalamounová, Z. (2012). Komunikace ve školní třídě. Praha: Portál.

Tůma, F. (2014). Dialogismus a výzkum interakce ve třídě? Přehledová studie (19902012). Pedagogika, 64(2), 177-199. 